\title{
STRATEGI DAKWAH KULTURAL NAHDLATUL ULAMA DAN MUHAMMADIYAH DI KABUPATEN BANYUMAS
}

\author{
Abdul Basit *
}

\begin{abstract}
Conceptually, the cultural da'wa (preaching) of NU and Muhammadiyah are based on bilhikmah (wisdom) principle stated in Quran. Since it was founded, NU has applied that principle as it can be seen from the da'wa by Walisongo; whereas Muhammadiyah formally present cultural da'wa as a discourse in 2002. In the application, NU cultural da'wa in Banyumas Regency is focused on the process of purification and tajdid of Nahdliyin's religious understanding and attitudes, while Muhammadiyah cultural da'wa in Banyumas Regency is focused on the diversification of da'wa methods. In addition, NU cultural da'wa is appied through oral da'wa, written da'wa, and direct practice in the society. Similari methods of da'wa is also done my Muhammadiyah. However, socialization through the organization can be clearly seen in Muhammadiyah cultural da'wa. Although there are some differences in the socialization and application, the strategy of cultural da'wa is relevan to be applied in the plural society such as in Indonesia because cultural da'wa promotes a da'wa which is peaceful, humanistic, and accommodating to local culture.
\end{abstract}

Keywords: cultural da'wa, NU, Muhammadiyah, local cuitures.

\section{A. PENDAHULUAN}

Di Indonesia, Muhammadiyah dan Nahdlatul Ulama (selanjutnya disebut NU), yang merupakan dua organisasi Islam yang memiliki massa terbesar dan menjadi mainstream dalam gerakan dakwah di Indonesia, memiliki tanggung jawab besar dalam memecahkan umat. Apalagi, Muhammadiyah dan NU telah mengklaim sebagai organisasi pembaru. Sudah sepantasnya apabila kedua organisasi tersebut dapat memberikan terobosan-

\footnotetext{
•) Penulis adalah dosen tetap Jurusan Komunikasi (Dakwah) STAIN Purwokerto.
} 
terobosan baru dalam memahami ajaran Islam sehingga ajaran Islam benar-benar dapat berfungsi di tengah-tengah masyarakat.

Sejak awal pembentukannya (1912) sampai menjelang tahun 2000, gerakan dakwahnya lebih berorientasi pada purifikasi atau gerakan dakwah yang anti TBC (Takhayul, Bid'ah, dan Churafat). ${ }^{1}$ Implikasi dari gerakan dakwah tersebut, Muhammadiyah diklaim sebagai organisasi Islam yang menolak adanya budaya lokal yang berkembang di Indonesia. Sebaliknya, NU yang berdiri pada tahun 1926 merupakan organisasi yang lahir dari perjalanan panjang sejumlah ulama pesantren yang berusaha mengorganisir diri dan berjuang demi melestarikan budaya keagamaan maupun tradisi lokal kaum muslimin. ${ }^{2}$

Perbedaan kedua organisasi dalam menyikapi adanya budaya lokal, dalam perkembangan berikutnya memiliki titik pencerahan. Muhammadiyah yang dianggap "resisten" terhadap budaya lokal, sejak Musyawarah Tarjih ke-23 pada tahun 1995 di Aceh dan Munas Tarjih ke-25 di Jakarta pada Juli 2000, mulai mengalami pergeseran dalam menyikapi adanya budaya lokal. Muhammadiyah mulai mengakomodir adanya pluralitas budaya lokal. Bahkan, dalam sidang Tanwir Muhammadiyah di Bali pada tanggal 24-27 Januari 2002, Muhammadiyah mewacanakan adanya dakwah kultural. Melalui wacana tersebut, Muhammadiyah telah beranjak pada penyiapan strategi dakwah kultural.

Sementara NU, menurut Hasyim Muzadi, sampai saat ini tetap konsisten pada jalur kulturalnya. Memilih strategi dakwah kultural tak lain adalah upaya melestarikan prestasi dakwah para muballigh Islam awal di bumi Nusantara yang lebih terkenal dengan sebutan Walisongo. Strategi dakwah Walisongo merupakan best-practice dalam menjalin hubungan baik dengan tradisi dan kultur masyarakat lokal, yakni dengan memperlihatkan kesantunan ajaran Islam disertai perilaku-perilaku ramah dan meneduhkan, sehingga tampilan wajah Islam memiliki daya tarik dan memukau kepada penduduk pribumi yang pengaruhnya terus meluas hingga ke pusat-pusat kekuasaan kerajaan di masa itu. $^{3}$ 
Dengan demikian, Muhammadiyah dan NU pada saat ini memiliki titik temu dalam mengembangkan dakwah kultural, yakni sebuah gerakan dakwah yang mengusung tema-tema genuine keindonesiaan sehingga sangat kontekstual dan "membumi". ${ }^{4}$ Oleh sebab itu, dakwah kultural bukanlah strategi dakwah melawan sesama umat Islam, tetapi melakukan kontekstualisasi tafsir-tafsir atas doktrin dengan problem-problem yang muncul di tengah masyarakat Islam. ${ }^{5}$

Untuk mengetahui lebih jauh mengapa Muhammadiyah dan NU memilih strategi dakwah kultural dan bagaimana strategi dakwah kultural Muhammadiyah dan NU diimplementasikan dalam tataran praktis di wilayah Indonesia, maka penulis meneliti tentang strategi dakwah kultural Muhammadiyah dan NU di kabupaten Banyumas sebagai studi kasus. Dalam studi kasus ini, penulis menggunakan pendekatan kualitatif dengan cara mengungkap secara holistik strategi dakwah kultural NU dan Muhammadiyah Banyumas, yang di dalamnya akan diperdalam tentang alasan-alasan NU dan Muhammadiyah memilih strategi dakwah kultural, proses sosialisasi ke masyarakat, dan bentukbentuk kegiatan yang dilakukan.

Langkah yang ditempuh oleh penulis dalam menggali data, pertama-tama penulis mengkaji dokumen yang berkaitan dengan konsepsi dakwah kultural yang diusung oleh organisasi NU dan Muhammadiyah. Selanjutnya, penulis melakukan wawancara mendalam kepada pengurus NU dan Muhammadiyah serta para aktivis dakwah dari kedua organisasi tersebut. Hasil penggalian data tersebut dianalisis dengan cara memilah-milah data sesuai dengan rumusan masalah yang dikembangkan dan teori yang digunakan. Proses penggalian data dan analisis data dilakukan secara berkesinambungan, seperti yang diungkapkan oleh Mile dan Huberman yang menggambarkan analisa penelitian kualitatif yaitu terjadi sirkulasi antara pengumpulan data, penyajian data, reduksi data, dan kesimpulan-kesimpulan. Semuanya dilakukan dalam proses yang tidak terpisah. ${ }^{6}$ 


\section{B. KONSEPSI DAKWAH KULTURAL MUHAM- MADIYAH DAN NU}

Konsepsi dakwah kultural Muhammadiyah digulirkan pertama kali dalam Sidang Tanwir di Denpasar (Bali) pada tanggal 24-27 Januari 2002. Berdasarkan saran dan masukan dalam sidang Tanwir tersebut disusunlah draft konsepsi dakwah kultural yang diketuai oleh Watik Pratiknya dan Haedar Nashir. Setelah konsep dakwah kultural dianggap memadai, kemudian diajukan dalam Sidang Tanwir di Makasar pada Juni 2003. Dalam sidang tersebut, akhirnya konsep dakwah kultural diterima dengan sedikit perubahan dan perbaikan.

Latar belakang munculnya strategi dakwah kultural Muhammadiyah disebabkan karena tantangan dan permasalahan yang dihadapi umat manusia semakin kompleks, sehingga batas-batas antara yang ma'ruf dan yang munkar sudah semakin sulit untuk dipisahkan. ${ }^{7}$ Dalam satu media, satu ruang dan satu waktu bisa menampilkan dua wajah sekaligus yaitu antara yang munkar dan yang ma'ruf. Manusia sering kehilangan patokan moral dan akhlak, bahkan mengalami krisis moral dan spiritual.

Untuk menghadapi kondisi tersebut, Muhammadiyah mengembangkan strategi kebudayaan dan strategi perubahan sosial melalui dakwah kultural. ${ }^{8}$ Dalam bahasa yang tidak jauh berbeda, menurut Subur Widadi, kemunculan dakwah kultural didasari pada realitas sosial dimana dunia ini sudah tidak bisa menghindari keanekaragaman dalam segala bidang. Muhammadiyah, sebagai organisasi keagamaan dalam melaksanakan misi dakwahnya memerlukan strategi khusus agar tidak ditinggalkan oleh objek dakwah. Dakwah kultural menjadi salah satu pilihan bagi organisasi Muhammadiyah. ${ }^{9}$

Selanjutnya, Subur Widadi menyatakan bahwa dakwah kultural dipahami sebagai dakwah berbasis kultur yang bersifat majemuk. Artinya, dakwah kultural sama dengan dakwah multikultural dimana "multi" di sini meliputi semua aspek kehidupan manusia dan tidak hanya berdimensi budaya dalam arti sempit seni saja. ${ }^{10}$ Sedangkan menurut Sutopo Aji, dakwah kultural 
adalah bagaimana kita menyampaikan ajaran Islam yang sesuai dengan tuntunan Rasul dengan bahasa keumatan atau dengan lingkungan tertentu. Artinya, dakwah dilakukan sesuai dengan audiens dan kultur lokalnya. ${ }^{11}$

Pemahaman kedua dai Muhammadiyah Banyumas tersebut sesuai dengan konsepsi dakwah kultural yang dikembangkan oleh Pimpinan Pusat Muhammadiyah yaitu upaya menanamkan nilainilai Islam dalam seluruh dimensi kehidupan dengan memperhatikan potensi dan kecenderungan manusia sebagai mahluk budaya secara luas, dalam rangka mewujudkan masyarakat Islam yang sebenar-benarnya. ${ }^{12}$

Pada dasarnya, konsepsi dakwah kultural Muhammadiyah merupakan tindak lanjut dari gerakan dakwah jama'ah yang diusung oleh Muhammadiyah sejak tahun 1971 berdasarkan hasil Muktamar ke-38 di Makasar. Gerakan dakwah jamaah yang berbasis komunitas atau kelompok tersebut dapat menjadi subjek, media dan wahana dalam mengembangkan strategi dakwah kultural. Dalam bahasa yang lain, dakwah kultural Muhammadiyah dapat dikatakan sebagai payung besar yang mencakup konsep-konsep dakwah Muhammadiyah yang sudah ada dengan melakukan perluasan pada ruang lingkup, pendekatan, metode, dan strategi.

Dakwah kultural Muhammadiyah berbasis pada prinsip bahwa memahami potensi dan kecenderungan manusia sebagai makhluk budaya berarti memahami ide-ide, adat istiadat, kebiasaan, nilai-nilai, norma, sistem aktivitas, simbol dan hal-hal fisik yang memiliki makna tertentu dan hidup subur dalam kehidupan masyarakat. Pemahaman tersebut dibingkai oleh pandangan dan sistem nilai ajaran Islam yang membawa pesan rahmatan lil'alamin. Dengan demikian, dakwah kultural menekankan pada dinamisasi dakwah, ${ }^{13}$ selain pada purifikasi. ${ }^{14}$

Berkaitan dengan konsep bid'ah? Muhammadiyah berpandangan bahwa tidak ada bid'ah yang hasanah karena menurut Hadis Nabi, "Seluruh bid'ah adalah sesat, dan tiap-tiap yang sesat akan masuk neraka". Bid'ah Menyangkut action (perbuatan), dan orang yang berbuat bid'ah adalah orang yang mengajak kegiatan- 
kegiatan ibadah atau sosial-keagamaan yang tidak ada dasarnya baik dari al-Qur'an, Hadis maupun hasil ijtihad. Sementara itu, maslahah mursalah lebih ditekankan pada pembebasan kepada umat untuk memilih sesuatu yang tidak bertentangan dengan manhaj Muhammadiyah. Oleh karena itu, Muhammadiyah mengaturnya dalam Pedoman Hidup Islami (PHI) dan keputusan tarjih sehingga warga Muhammadiyah dapat terarah sesuai dengan manhaj Muhammadiyah. ${ }^{15}$

Berkaitan dengan tradisi, prinsip dasar yang digunakan oleh Muhammadiyah tergantung pada asbabul wurud (asal-usul) tradisi tersebut. Selanjutnya, apakah tradisi tersebut sesuai atau tidak, Muhammadiyyah menggunakan patokan yaitu: Pertama, apakah tradisi tersebut ada dasarnya atau tidak di dalam alQur'an dan Hadis. Kedua, jika ada dasarnya apakah Hadis yang digunakan itu shoheh atau tidak. Ketiga, apakah tradisi tersebut memberikan manfaat atau tidak. ${ }^{16}$

Berbeda dengan konsepsi dakwah kultural Muhammadiyah seperti diuraikan di atas, NU, dalam mengembangkan dakwah kulturalnya, tidak terbangun dari konsepsi yang tersusun secara sistematis baik melalui kajian ilmiah maupun dari hasil Kongres NU. Hal ini dikarenakan aktivitas dakwah NU sejak awal berdirinya tidak terlepas dari upaya untuk memperjuangkan dan mempertahankan tradisi dan budaya lokal. Sejak awal, gerakan dakwah NU memiliki komitmen untuk mengembangkan dakwah kultural. Konsistensi NU untuk memilih model dakwah kultural tidak lain adalah sebagai upaya melestarikan prestasi dakwah para Walisongo. Mereka telah berhasil menjalin hubungan yang baik dengan masyarakat setempat berikut tradisi maupun kultur lokal. ${ }^{17}$

Dakwah kultural yang dilakukan oleh Walisongo itulah yang dijadikan konsep dasar dalam pengembangan dakwah kultural di NU. Menurut Sutrisno Usman yang mengutip pendapat Jalaluddin Rahmat, dakwah model Walisongo inilah yang telah berhasil mengislamkan wilayah Indonesia, ${ }^{18}$ karena dakwah kultural sangat memperhatikan audiens yang akan didakwahkan.

Secara umum, audien dari dakwah NU adalah kalangan masyarakat menengah ke bawah. Mereka umumnya berada di 
pedesaan-pedesaan dan sebagian kecil di wilayah perkotaan. Dari segi kepercayaan, mereka masih berpegang teguh pada tradisi dan budaya lokal yang terkadang kental dengan nuansa magis yang masih mengakar kuat di wilayah Banyumas.

Dengan kondisi audiens semacam itu, maka dakwah NU, menurut Sutrisno Usman, lebih menekankan pada pemberian pemahaman dan penjelasan yang intinya tidak menabrak ajaran agama dan tidak menabrak tradisi. ${ }^{19}$ Jika ada tradisi atau budaya lokal yang sedikit menyimpang dari ajaran Islam, maka secara perlahan (evolusi) para da'i memberikan penjelasan dan pemahaman agar jama'ah mau meninggalkan dan merubah tradisi tersebut agar relevan dengan ajaran Islam. Sebagai contoh, pada 20 tahunan yang lalu, kepercayaan masyarakat Banyumas masih begitu kental bahwa sebelum melaksanakan ibadah puasa mereka seakan mewajibkan diri mereka untuk melaksanakan "nyekar" ke makam. Sekarang ini berkat adanya dakwah yang dilakukan oleh para da'i NU secara evolutif, mereka yang melakukan "nyekar" sudah mulai menurun. Para da'i menjelaskan bahwa ziarah kubur dapat dilakukan kapan saja dan fungsinya adalah untuk mendoakan orang tua dan kaum muslimin serta untuk ingat akan kematian bagi orang yang berziarah.

Selanjutnya, dalam bersikap dan berperilaku orang-orang Nahdiyin menggunakan kerangka berpikir yang didasarkan kepada ajaran ahlussunnah waljama'ah yang memiliki ciri tawassuth (moderat), tasammuh (toleran), ishlah (reformatif), tathowwur (dinamis) dan manhajiyah (metodologis). Prinsip-prinsip dasar tersebut merupakan pilihan dan keyakinan yang diturunkan dan dicontohkan oleh Rasulullah. Dalam hal ini, Rasulullah telah memberikan pelajaran yang berharga kepada umatnya, yaitu jangan mengambil titik ekstrim (tafrith) terhadap dua pilihan, sebab sabda beliau "khairul umur ausatuha" (sebaik-baik perkara adalah tengah-tengah). Artinya, kita tidak bisa menolak mentahmentah apa yang ditawarkan globalisasi asalkan hal itu secara jelas tidak bertentangan dengan nas agama. Begitu pun juga kita tidak mau berkutat terus menerus dalam kubangan tradisi yang membabibuta sehingga mengakibatkan tertinggal dan terus 
dijadikan sebagai objek penderita. Dengan kerangka berpikir tersebut, konsepsi dakwah kultural NU berpedoman pada almuhafadlatu ala al-qadim al-shalih wa al-akhdzu bi al-jadid al-ashlah (memelihara yang baik dari tradisi lama dan mengambil budaya baru yang lebih baik) dan prinsip "hikmah" seperti yang tercantum dalam Al-Qur'an surat An-Nahl ayat $125 . .^{20}$

\section{SOSIALISASI DAKWAH KULTURAL MUHAM- MADIYAH DAN NU}

Dakwah di Muhammadiyah, menurut M. Hizbul Muflihin,,11 tidak bisa dilepaskan dari perintah yang ada dalam al-Qur'an surat Ali-Imran ayat 104, yang oleh sebagian orang dianggap sebagai ayat Muhammadiyah. Istilah waltakun yang terdapat dalam surat Ali-Imran tersebut merupakan keharusan atau kewajiban bagi setiap umat Islam untuk melakukan dakwah. Sedangkan kata minkum bisa diartikan seluruh umat Islam, bisa juga hanya sebagian. Makna minkum yang bersifat tab'idhiyyah atau sebagian inilah yang dijadikan landasan untuk mengadakan dakwah melalui persyarikatan Muhammadiyah.

Di Muhammadiyah terdapat dua bidang dakwah yaitu lembaga dakwah khusus yang menangani masyarakat terpencil atau masyarakat yang membutuhkan dakwah khusus, seperti daerah transmigran, dan ada lembaga dakwah umum yang disebut dengan majelis tabligh. Mengingat kedua bidang ini terkadang kerjanya saling melengkapi, maka sejak muktamar ke44 tahun 2000 kedua bidang ini digabungkan menjadi satu lembaga yang disebut dengan Majelis Tabligh dan Dakwah Khusus (MTDK). Dilihat dari prinsip dan visi misi, dakwah Muhammadiyah Kabupaten Banyumas tidak terlepas dari prinsip dan visi misi yang dikembangkan oleh MTDK Pusat, tetapi dalam pengembangan program masing-masing wilayah terhadap kebebasan untuk mengembangkannya. MTDK disebut sebagai "bengkel dakwah" dimana di dalamnya ditentukan metode dan strategi dalam berdakwah. MTDK inilah yang menjadi benteng utama dalam melakukan sosialisasi dakwah kultural dan proses pengkaderan da'i di Muhammadiyah. 
Selain itu, Pimpinan Pusat Muhammadiyah secara langsung melakukan sosialisasi konsep dakwah kultural melalui penerbitan khusus oleh Majalah Suara Muhammadiyah yang pertama kali dicetak pada tahun 2004. Selanjutnya, beberapa tokoh Muhammadiyah dan MTDK menerbitkan beberapa buku yang berhubungan dengan dakwah kultural, yaitu Agama dan Pluralitas Budaya Lokal; ${ }^{22}$ Muhammadiyah Sebagai Tenda Kultural; ${ }^{23}$ Dakwah Islam Kontemporer;, ${ }^{24}$ Membumikan Dakwah Kultural;, ${ }^{25}$ dan Landasan Dakwah Kultural; ${ }^{26}$

Muhammadiyah membedakan objek dakwah menjadi (1) umat ijabah, dan (2) umat dakwah. Umat ijabah yaitu objek dakwah yang dinilai telah memiliki pemahaman tentang Islam secara mencukupi, mempunyai keilmuan di atas rata-rata dan mereka diidentifikasi sebagai kelompok objek dakwah yang tidak akan mudah diombang-ambingkan oleh iming-iming dari luar. Perlakuan dakwah terhadap kelompok objek dakwah jenis ini melalui pendekatan "bilkhoir" melalui dalil-dalil naqli. Seorang dai yang bertugas adalah mereka yang kuat dalam hal tekstual maupun kontekstual dalam bentuk aplikasinya. Model dakwah demikian, relatif lebih mudah karena bekal yang telah dibawa oleh objek dakwah.

Objek dakwah yang kedua merupakan kelompok masyarakat yang belum mempunyai pondasi keimanan yang kuat, istilah lainnya Islam abangan atau KTP. Mereka masih kukuh memegang tradisi yang dinilai berbau dengan kemusyrikan. Selain itu, dakwah ini juga ditujukan bagi orang di luar agama Islam. Tetapi karena aturan formal tidak mengijinkan dakwah (mengajak) orang yang telah beragama, maka khusus dakwah diadakan secara pasif tetapi terbuka.

Metode dakwah yang digunakan terhadap objek dakwah yang kedua menggunakan pendekatan "bilma'ruf", yaitu melalui dalildalil aqli. Sebagai gambaran, perintah berbuat baik kepada orang tua, jika disampaikan kepada umat ijabah, cukup disampaikan dalil-dalil naqlinya. Hal ini sudah mencukupi karena mereka dapat mencernanya sendiri. Sebaliknya, terhadap umat dakwah, perlu disampaikan urgensi berbuat baik kepada orang tua, 
mengenai hukum-hukum karma, dan baru disampaikan dalil-dalil naqlinya.

Dakwah kultural juga disosialisasikan melalui programprogram amal Muhammadiyah. Seperti pendirian BMT, Panti Asuhan, Sekolah dan Perguruan Tinggi, serta Rumah Sakit. Program-program amal Muhammadiyah ini sebagai media dakwah untuk menyemaikan nilai-nilai Islam, terutama di wilayah Banyumas. Bahkan, Muhammadiyah Banyumas bahkan telah berupaya melakukan proses dakwah kulturalnya melalui kegiatan pertunjukan seni wayang. Hal ini ditempuh dengan pertimbangan masih banyak warga terutama yang masih abangan menyukai hasil kebudayaan ini. Di sisi yang lain, pertunjukan wayang ternyata sering diramaikan oleh hal-hal negatif seperti perjudian. Karena itu perlu ada langkah aplikatif untuk mengatasinya. Rekayasa wayang dengan mengubah lagu-lagu (sulukan) dengan memasukkan nilai-nilai al-Qur'an maupun Hadis. Selain itu, sebelum wayangan, diawali dengan pengajian yang berupa pengantar tentang isi dari pertunjukan tersebut. Metode ini terbukti berhasil dengan selalu antusiasnya orang-orang menyaksikan. Mereka - penonton - rata-rata orang yang masih abangan, di mana mereka tidak pernah mau mengaji tetapi dengan media wayang, mereka mulai mempelajari Islam. Alhasil, Muhammadiyah mulai mengadopsi metode walisongo dalam menyebarkan Islam. ${ }^{27}$ Tentunya ini merupakan hal baru dalam ormas terbesar setelah NU.

Bentuk kegiatan dakwah kultural yang dilakukan oleh Muhammadiyah Banyumas yaitu: pertama, pengajian rutin tingkat cabang yang diadakan berdasarkan pada hitungan hari pasaran (pahing, manis, pon, wage, dan seterusnya) dan berdasarkan zone (ada lima zone di wilayah kabupaten Banyumas). Penceramahnya ada yang senior dan yunior serta dikoordinasikan oleh pengurus cabang. Kedua, penerbitan buletin dakwah. Ketiga, pendidikan kader muballigh. Keempat, training ketrampilan. Kelima, pembuatan peta dakwah. Keenam, monitoring kegiatan dakwah. Ketujuh, pentas budaya di mana Muhammadiyah memiliki group kesenian "panembromo" yang diketuai oleh Subur Widadi. Kedelapan, 
baitul arqom atau pendidikan dasar bagi kader-kader atau pengurus. Kesembilan, pembuatan dan perlombaan penulisan naskah dakwah.

Menurut Sutopo Aji, sosialisasi konsepsi dakwah kultural Muhammadiyah di kalangan para elite Muhammadiyah telah berhasil dipahami, namun di kalangan para jama'ah atau tokohtokoh Muhammadiyah di cabang atau di wilayah-wilayah terpencil belum banyak memahami dakwah kultural. Sebagai contoh, masih ada beberapa orang Muhammadiyah mengikuti tradisi lokal "yang tidak sejalan dengan manhaj Muhammadiyah" karena pemahaman yang kurang dan terkadang hanya sekedar untuk menghormati. Padahal Muhammadiyah sudah memberikan penjelasan melalui tarjih dan Pimpinan Muhammadiyah telah menginstruksikan hasil tarjih agar dijalani dan lembaga di tingkat bawah yang mengawalnya. ${ }^{28}$

Tidak berbeda dengan Muhammadiyah, aktivitas dakwah yang dilakukan oleh NU ditangani oleh satu lembaga khusus yang dikenal dengan Lembaga Dakwah Nahdlatul Ulama (LDNU). LDNU adalah perangkat departemen organisasi NU yang berfungsi sebagai pelaksana kebijakan NU di bidang dakwah dan pengembangan agama Islam yang menganut paham ahlussunnah wal jama'ah. LDNU dibentuk pada tanggal 23 Rajab $1406 \mathrm{H}$ bertepatan dengan tanggal 3 April $1986 \mathrm{M}$ oleh Pengurus Besar NU sebagai upaya pengembangan gerakan dakwah Islam untuk waktu yang tidak terbatas.

Visi dari LDNU adalah terwujudnya dakwah Islam ahlussunnah wal jama'ah yang kontekstual, profesional, konseptual, ramah, amanah dan terbuka, dengan berpegang pada prinsip tawasuth (moderat), tasamuh (toleran), tawazun (seimbang), dan $i^{\prime}$ tidal (keadilan). Adapun Tugas LDNU adalah untuk memformulasi model dakwah kultural warisan Walisongo demi menjaga kesinambungan dan kelangsungan syiar Islam ahlussunnah waljama'ah di bumi nusantara ini. Selain itu, LDNU berfungsi sebagai garda depan dalam mensosialisasikan nilai-nilai Islam inklusif, moderat dan toleran yang mencerminkan Islam rahmatan lil'alamin. LDNU juga dituntut mengembangkan program- 
program dakwah kultural yang lebih inovatif dan tidak lupa mempersiapkan kader-kader dakwah yang handal, tangguh dan memiliki pengetahuan keislaman yang mumpuni di samping skill berdakwah di tengah-tengah kehidupan masyarakat yang terus berkembang.

Untuk menjaga nilai-nilai historis NU berpedoman pada garisgaris perjuangannya (khiththah) serta menjaga konsistensi warga nahdliyin berada pada koridor yang telah ditetapkan, NU membuat fikrah Nahdliyah. Fikrah Nahdliyah adalah kerangka berpikir yang didasarkan pada ajaran ahlussunnah waljama'ah yang dijadikan landasan berpikir NU untuk membentuk arah perjuangan dalam rangka perbaikan umat.

Dalam merespon persoalan, baik yang berkenaan dengan persoalan keagamaan maupun kemasyarakatan, NU memiliki manhaj ahlussunnah waljama'ah sebagai berikut:

1. Dalam bidang akidah/teologi, NU mengikuti manhaj dan pemikiran Abu Hasan Al-Asy'ari dan Abu Mansur AlMaturidi.

2. Dalam bidang figh/hukum Islam, NU bermadzhab secara qauli dan manhaji kepada salah satu al-madzahib al-arba'ah (Hanafi, Maliki, Syafi'i dan Hambali).

3. Dalam bidang tasawuf, NU mengikuti Imam Al-Junaid alBaghdadi (W. 297 H) dan Imam Abu Hamid Al-Ghazali (W. $505 \mathrm{H})$.

Dalam melakukan sosialisasi terhadap fikrah manhajiah ahlussunnah waljama'ah dan konsepsi dakwah kultural, NU melakukan proses kaderisasi dai dan guru-guru yang terlibat secara langsung di masyarakat. Pemberian pemahaman dan penjelasan ini dilakukan umumnya melalui forum-forum pengajian yang diadakan secara rutin oleh para muballigh di majelis-majelis ta'lim dan pengajian yang diadakan oleh pengurus seperti pengajian di Muslimat, lailatul ijtima' (pengajian di pengurus majelis wakil cabang/ranting) dan berbagai Peringatan Hari Besar Islam (PHBI).

Pengajian yang dilakukan di kalangan NU cenderung mentransfer konsep-konsep dari para ulama terdahulu. Meski forumforum pengajian yang diadakan terkadang kurang terkoordinasi 
dan terkontrol secara organisatoris, tetapi keberadaan forum pengajian ini masih mendominasi kegiatan dakwah yang ada di NU Cabang Banyumas. Bahkan, kegiatan forum pengajian ini seakan menutupi kegiatan-kegiatan dakwah lainnya yang dilakukan oleh NU dan hal ini juga secara tidak langsung membangun paradigma bahwa dakwah itu hanyalah bersifat tabligh (penyampaian saja). Padahal dakwah yang dilakukan oleh Rasulullah tidak hanya bersifat tabligh saja, melainkan juga menanamkan nilai-nilai kebaikan (QS. 33:21, 61:2) dan membentuk masyarakat Islam dalam semua segi kehidupan.

NU mengakui kelemahan dakwahnya terletak pada lemahnya manajemen. Ini bertitik tolak dari cara pandang NU yang lebih mengedepankan hakikat daripada syariat. Sebagai contoh, NU lebih condong pada konsep wahbiy dibandingkan dengan konsep kasbiy dalam mencari rizki. Sehingga disinyalir warga NU memiliki etos kerja yang lemah. Sebaliknya, Muhammadiyah lebih condong menggunakan konsep kasbi. Kecenderungan masingmasing ini tentunya mempunyai kelemahan. Idealnya ada balancing di antara keduanya. Sebagai gambaran dalam penerapan konsep wahbi, banyak panti asuhan NU membiayai institusinya hanya bermodalkan keyakinan. Mereka tidak mempunyai badan usaha atau melakukan langkah-langkah real yang progresif (misal mencari donatur) untuk memberi makan anak-anak yatim. Tetapi, nyatanya untuk sekian lama panti asuhan tersebut dapat bertahan sampai saat ini, meski dalam kondisi seadanya. Ini termasuk konsep wahbi dalam NU. Cara pandang demikian teraplikasi sampai dengan tingkat manajemen dakwah, segala sesuatu akan dikembalikan kepada Yang Di Atas.

Kelemahan lain dari manajemen dakwah NU disebabkan karena sebagian besar warga NU lebih menonjolkan figur seorang Kyai atau Ustadz sehingga penciptaan kepemimpinan yang bersifat kolektif kurang terakomodir. Akibatnya, kemajuan dan keberhasilan dakwah lebih ditentukan oleh nama besar dan kharismatik seorang Kyai atau Ustadz.

Meski demikian, peran Kyai atau Ustadz amat berpengaruh dalam mentransfer dan mempraktikkan Islam kultural di 
masyarakat, terutama di pondok pesantren. Pesantren diakui sebagai pewaris tradisi intelektual Islam tradisional yang memiliki peran: Pertama, sebagai pusat berlangsungnya transmisi ilmu-ilmu keislaman. Kedua, sebagai penjaga dan pemelihara keberlangsungan Islam. Ketiga, sebagai pusat reproduksi ulama. ${ }^{29}$ Dengan peran tersebut, pesantren merupakan media yang kokoh bagi NU dalam mengembangkan strategi dakwah kulturalnya. Melalui pondok pesantren inilah tradisi Islam ahlussunnah waljama'ah yang dikembangkan oleh Walisongo terus tumbuh subur di kalangan santri dan masyarakat Indonesia.

Di pesantren juga berkembang tarekat yang diakui sebagai salah media untuk mensosialisasikan dan mempraktikkan dakwah kultural. Tarekat dilakukan tidak seperti pengajian yang cenderung menggunakan konsep ajakan, tarekat bersifat pasif dan lebih mengandalkan kesadaran individu serta hidayah dari Allah. Artinya, orang yang masuk tarekat memang mereka yang dibimbing oleh Allah untuk menuju tarekat yang diikuti. ${ }^{30}$

Dakwah kultural melalui tarekat ditujukan kepada orangorang yang telah mempunyai keimanan kuat. Hal ini karena untuk mengikuti sebuah gerakan tarekat, seseorang harus dibai'at dan mempunyai konsekuensi mengamalkan wirid khusus yang hukumnya menjadi wajib untuk dijalankan. Wirid yang dibaca, diyakini berasal dari Nabi SAW melalui Sahabat-sahabat tertentu. Tarekat yang resmi atau legal ${ }^{31}$ mempunyai silsilah mursyid yang jelas sampai Nabi SAW. Silsilah tersebut menunjukkan uruturutan jalur yang bersifat estafet. Hanya seorang mursyid yang ditunjuk oleh mursyid sebelumnya yang mempunyai otoritas membai'at seorang jamaah tarekat.

Sasaran pokok tarekat yakni pada perubahan sikap dan perilaku jama'ah dalam berhubungan dengan Tuhan dan sesama. Dalam mempengaruhi objek dakwah, pendekatan spiritual sangat kental. Misalnya, sebelum pengajian diadakan wiridan dengan bacaan-bacaan tertentu. Wiridan-wiridan yang dibaca berbarengan dengan suara yang keras, seringkali dapat membuat orang menangis teringat akan dosa-dosa atau tersadar akan kekerdilan diri sampai mengalami ekstase. Dalam level tersebut, hati manusia 
siap untuk menerima kebenaran. Barulah, nilai-nilai Islam disampaikan melalui pengajian atau mau'idzat al-hasanah.

Dakwah kultural NU juga disosialisasikan melalui penerbitan majalah seperti Risalah dan buletin asy-Syifa. Majalah dan buletin inilah yang menjadi media untuk memberikan penjelasan dan pemahaman berbagai problem dakwah dan kehidupan yang muncul di kalangan warga NU, terutama berkenaan dengan berbagai kritik terhadap pelaksanaan keberagamaan warga nahdliyin yang "kental" dengan budaya lokal.

Dengan demikian, sosialisasi dakwah kultural NU, tidak hanya dilakukan melalui dakwah secara lisan, melainkan juga melalui tulisan dan praktik langsung ajaran Islam yang mengakomodir budaya lokal yang ada di masyarakat. Jika ada budaya lokal yang menyimpang, maka metode yang digunakan NU dengan memasuki 'wilayah' budaya tersebut secara langsung, terlibat secara intensif, dan oleh karenanya akan ditemukan celahcelah untuk mulai dakwahnya, yakni memberikan penjelasan, pemahaman dan pelurusan yang sesuai dengan Islam ahlussunnah waljama'ah tentunya.

\section{STRATEGI DAKWAH KULTURAL MUHAM- MADIYAH DAN NU}

Dakwah kultural merupakan sebuah keharusan. Mengingat kehadiran suatu agama (Islam) akan bergerak dan tumbuh melalui wadah kultural, sehingga muncul kultur yang berciri keagamaan atau simbol-simbol kultural yang digunakan untuk mengekspresikan nilai keagamaan. ${ }^{32}$ Karenanya, Islam yang sampai ke Indonesia pun sudah berbaur dengan konstruksi historis dan penafsiran sehingga di hadapan kita sekarang ini terdapat beragam mazhab dan warna lokalitas kultural.

Dalam konteks dakwah, adanya keniscayaan pergumulan antara Islam dengan lokalitas kultural menuntut para da'i atau lembaga dakwah mengembangkan strategi dakwah yang bijaksana. Metode dakwah bil-hikmah, seperti yang dijelaskan dalam Al-Qur'an surat an-Nahl ayat 125 merupakan prinsip yang tepat untuk melaksanakan dakwah kultural. Pada konteks inilah 
dakwah kultural Muhammadiyah dan NU Banyumas memiliki titik persamaan.

Begitu juga, secara konseptual dakwah kultural Muhammadiyah dan NU sama-sama dimaksudkan untuk mengajak seseorang atau objek dakwah ke jalan Islam dengan memperhatikan budaya lokal yang ada di masyarakat atau lingkungan dimana mad'u tersebut berada. Titik perbedaan terletak pada aplikasinya di lapangan. NU yang konsisten dengan jalur kulturalnya sejak berdiri dan mengikuti dakwah yang dilakukan oleh Walisongo, belum merumuskan secara sistematis bagaimana strategi dakwah kultural tersebut. Meskipun secara nyata telah melakukan dakwah kultural yang beorientasi pada pemberian penjelasan, pemahaman dan pelurusan terhadap budaya yang "menyimpang" dengan berpedoman pada al-muhafadlatu ala al-qadim alshalih wa al-akhdzu bi al-jadid al-ashlah (memelihara yang baik dari tradisi lama dan mengambil budaya baru yang lebih baik).

Sementara, Muhammadiyah yang pada awalnya "resisten" terhadap budaya dan tradisi lokal, membuat rumusan dakwah kultural sebagai tindak lanjut dari dakwah jama'ah yang dilakukan sebelumnya. Konsepsi dakwah kultural Muhammadiyah sebagai strategi kebudayaan atau payung besar bagi gerakan dakwah Muhammadiyah, dalam aplikasinya dijadikan sebagai media atau jalan dakwah (turuq al-da'wah) agar dakwah dapat dilakukan secara efektif dan jama'ah yang terlibat bisa dari berbagai kalangan.

Dengan demikian, strategi dakwah kultural NU cabang Banyumas lebih diarahkan pada proses "purifikasi dan tajdid" terhadap pemahaman dan sikap keberagamaan warga nahdliyin, sedangkan strategi dakwah kultural Muhammadiyah Daerah Banyumas lebih diarahkan pada "diversifikasi" metode dakwahnya.

\section{E. KESIMPULAN}

NU dan Muhammadiyah melakukan dakwah kultural dimaksudkan agar dakwah yang dilakukan dapat berjalan secara efektif dan efisien. Dakwah kultural dipahami sebagai sebuah strategi 
yang diturunkan dari perintah al-Qur'an yang menyatakan "ajaklah manusia ke jalan Tuhanmu dengan cara bijaksana (hikmah)" (QS. 16: 125). Perintah ini selanjutnya dijabarkan oleh Nabi saw dengan Hadisnya yang menyatakan "ajaklah manusia sesuai dengan kemampuan akalnya".

Selain itu, dakwah kultural yang dilakukan oleh kedua organisasi tersebut berpandangan bahwa Islam hadir ke dunia diperuntukkan kepada manusia yang memiliki kultur yang terbentuk dari interaksinya dengan lingkungannya. Karenanya, ajaran Islam yang didakwah oleh para da'i harus menyesuaikan dengan masyarakat setempat beserta tradisi dan budaya lokal yang ada di wilayah tersebut. Dengan cara demikian, dakwah bisa efektif. Ibaratnya kita menangkap ikan, terkena ikannya tetapi airnya tidak keruh. Artinya manusia yang diajak dakwah sadar dengan sendirinya dan mereka tidak tersinggung.

Dakwah kultural yang dilakukan oleh NU dan Muhammadiyah Banyumas secara esensial ada persamaan yakni bagaimana mendekati umat dengan cara mengapresiasi dan mengakomodir tradisi dan budaya lokal yang berkembang di masyarakat Banyumas. Meskipun demikian, secara teknis dan pada prinsip-prinsip yang dianut oleh organisasi tersebut ada beberapa perbedaan yang mendasar antara NU dengan Muhammadiyah yaitu:

1. Secara konsepsional, dakwah kultural NU kurang terformulasikan secara akademik dan organisatoris sehingga terkesan konsep dakwah kulturalnya hanya mengikuti tradisi dan budaya dakwah yang telah dilakukan oleh para pendahulu, khususnya dakwah yang dilakukan oleh para Walisongo. Sedangkan Muhammadiyah, dakwah kulturalnya dibangun dari hasil muktamar dan diskusi-diskusi ilmiah yang dilakukan oleh para ahli sehingga konsepsi dakwah kulturalnya lebih jelas dan dipahami oleh para anggota dan pengurus organisasi Muhammadiyah;

2. Dalam sosialisasi konsep dakwah kultural, NU melakukannya melalui tindakan-tindakan nyata berupa pengajianpengajian atau kegiatan-kegiatan keagamaan yang dilakukan 
oleh warga nahdliyin. Sedangkan Muhammadiyah dilakukan melalui proses organisasi yang cenderung hirarkis artinya konsepsi dakwah kultural yang dikembangkan di pusat, selanjutnya diberikan pemahaman kepada pengurus daerah dan cabang;

3. NU banyak menggunakan simbol-simbol keagamaan dalam membangun dakwah kulturalnya seperti kegiatan tarekat, mauludan, slametan, kesenian (wayang, hadrah, dan pentas musik), dan istighasah. Sementara, Muhammadiyah kurang atau bahkan tidak menggunakan simbol-simbol keberagamaan. Semua kegiatan dakwah kulturalnya dimaksudkan dalam kerangka menuju jalan dakwah. Perbedaan-perbedaan dalam sosialisasi dan pemaknaan simbol-simbol inilah yang pada akhirnya antara NU dan Muhammadiyah berbeda dalam penjabaran dakwah kulturalnya; dan

4. Dakwah kultural merupakan dakwah yang relevan untuk diterapkan pada era globalisasi. Melalui strategi dakwah kultural, unsur pemaksaan dan kekerasan ideologi dalam dakwah tidak akan terjadi. Dakwah akan dilakukan secara damai, harmonis dan memperhatikan lokalitas budaya.

\section{ENDNOTES}

${ }^{1}$ http://slamlib.com/id/artikel/dakwah-kultural-vs-imperialisme-Islammurni/

${ }^{2}$ Syamsul Ma'arif (Ed.), Potret Gerakan Dakwah NU (Jakarta: PP LDNU Publishing, 2007), hal. 4.

${ }^{3}$ Hasyim Muzadi, "Meneruskan Tradisi Berdakwah dari Para Pendahulu NU', dalam Ibid., hal. xxiv.

${ }^{4}$ Zakiyuddin Baidhawy mengartikan dakwah kultural dalam makna yang begitu luas yakni dakwah pro-TBC. Yakni: 1) dakwah yang memanfaatkan dan membangkitkan kemampuan imajinatif (takhayyul) individu dan masyarakat agar kehidupan semakin estetik (indah), holistik, simbolik (dalam arti beradab), dan cerdas; 2) dakwah yang mendorong, memotivasi, dan

mengkondisikan individu dan masyarakat untuk mencipta (kreatif) dan menemukan (inovatif) berbagai hal baru (bid'ah) baik dalam ide (pemikiran, wacana, teori dalam Muhammadiyah, dan masyarakat), aktivitas (praksis, gerakan Muhammadiyah), dan bentuk kebudayaan (amal-amal usaha Muhammadiyah); 3) serta dakwah yang mengeksplorasi seluruh kemampuan untuk meredefinisi "mitos" (baca: cita-cita sosial, meminjam istilah Mohammed Arkoun), 
mereproduksi, bahkan memproduksi mitos baru (khurafat) untuk mambangun citra keberagamaan, keber-Islam-an, dan keber-Muhammadiyah-an dalam rangka menuju masyarakat utama. Lihat http://Islamlib.com/id.

${ }^{5} \mathrm{http}: / /$ www.cmm.or.id/

${ }^{6}$ Mile dan Huberman, Analisis Data Kualitatif (Jakarta: UI-Press, 1992), hal. 20.

${ }^{7}$ Menurut M. Hizbul Muflihin, tantangan dan masalah dakwah yang dihadapi oleh Umat Islam adalah pemurtadan, ghazwul fikr, cultural imperialism (penjajahan/tekanan budaya Barat), sekulerisasi, kristenisasi, dan neo-sekulerisasi. Wawancara dengan M. Hizbul Muflihin, Ketua Majelis Tabligh dan Dakwah Khusus Muhammadiyah Banyumas, pada tanggal 28 Juli 2010.

${ }^{8}$ Pimpinan Pusat Muhammadiyah, Dakwah Kultural Muhammadiyah, Cet. Ke-2 (Jakarta: Suara Muhammadiyah, 2005), hal. 3.

${ }^{9}$ Wawancara dengan Subur Widadi, dai Muhammadiyah dan Pengurus Majelis Tabligh dan Dakwah Khusus Muhammadiyah Kabupaten Banyumas, pada tanggal 5 Agustus 2010.

${ }^{10}$ Wawancara dengan Subur Widadi.

${ }^{11}$ Wawancara dengan Sutopo Aji, da'i Muhammadiyah, pada tanggal 30 Juli 2010.

${ }^{12}$ Pimpinan Pusat Muhammadiyah, Dakwah Kultural, hal. 26.

${ }^{13}$ Dinamisasi dakwah berarti mencoba mengapresiasi potensi dan kecenderungan manusia sebagai makhluk budaya dalam arti luas, sekaligus melakukan usaha-usaha agar budaya tersebut membawa pada kemajuan dan pencerahan hidup manusia.

${ }^{14}$ Purifikasi merupakan faham yang mencoba untuk menghindari pelestarian budaya yang nyata-nyata dari segi ajaran Islam bersifat syirik, takhayul, bid'ah dan khurafat.

${ }^{15}$ Wawancara dengan Sutopo Aji.

${ }^{16}$ Wawancara dengan Hizbul Muflihin.

${ }^{17}$ Hasyim Muzadi, "Meneruskan Tradisi Berdakwah Dari Para Pendahulu NU”, dalam Samsul Ma'arif (Ed.), Potret Gerakan ......hal. xxi.

${ }^{18}$ Wawancara dengan Sutrisno Usman, Mantan Pengurus LDNU Kabupaten Banyumas dan penulis bulletin Asy-Syifa, pada tanggal 26 Juli 2010.

${ }^{19}$ Wawancara dengan Sutrisno Usman.

${ }^{20}$ Wawancara dengan K.H. Nur Hafidz, dai NU Banyumas, pada tanggal 7 Agustus 2010.

${ }^{21}$ Wawancara dengan M. Hizbul Muflihin.

${ }^{22}$ Buku ini merupakan hasil dari halaqah tarjih, sebagai forum intelektual untuk merumuskan strategi kebudayaan dan visi seni Muhammadiyah. Lihat Zakiyuddin Baidhawy dan Mutohharun Jinan (Ed.), Agama dan Pluralitas Budaya Lokal (Surakarta: Pusat Studi Budaya dan Perubahan Sosial UMS, 2003).

${ }^{23}$ Buku ini merupakan kepedulian orang-orang muda Muhammadiyah untuk ikut memikirkan bagaimana Muhammadiyah mampu merumuskan kembali 
jawaban-jawaban kontemporer terhadap masalah sosial dan kemanusiaan. Lihat Moeslim Abdurrahman (Ed.), Muhammadiyah Sebagai Tenda Kultural (Jakarta: Ideo Press \& Ma'arif Institute, 2003).

${ }^{24}$ Buku ini merupakan hasil dua kali (1995 dan 2000) kegiatan Dialog Dakwah Nasional yang diadakan oleh MTDK. Lihat Pimpinan Pusat Muhammadiyah, Dakwah Islam Kontemporer (Jakarta: MTDK, 2004).

${ }^{25}$ Buku ini merupakan salah satu pelengkap buku dakwah kultural yang dikeluarkan oleh Suara Muhammadiyah (2004). Lihat Jabrohim, Membumikan Dakwah Kultural (Jakarta: Suara Muhammadiyah, 2005).

${ }^{26}$ Buku ini sebagian besar merupakan hasil penelitian (disertasi) penulis yang dilakukan pada tahun 1990-an. Sebenamya buku ini tidak secara langsung berhubungan dengan dakwah kultural yang dilakukan oleh Muhammadiyah di Indonesia. Buku ini lebih melihat bagaimana al-Qur'an merespons adat kebiasaan Arab Jahiliyyah. Lihat Imam Muchlas, Landasan Dakwah Kultural (Jakarta: Suara Muhammadiyah), 2006.

${ }^{27}$ Wawancara dengan Subur Widadi.

${ }^{28}$ Wawancara dengan Sutopo Aji.

${ }^{29}$ Fahmi Arif El-Muniry, "Menggagas Pesantren Berbasis Riset: Dari Mengaji ke Mengkaji", Dalam Mihrab, Edisi II Tahun IV, 2006, hal. 77.

${ }^{30}$ Wawancara dengan $\mathrm{KH}$. Abu Chamid, mursyid tarekat dan pimpinan Pondok Pesantren Al-Ihsan Beji, Banyumas, pada tanggal 8 Agustus 2010.

${ }^{31} \mathrm{Di}$ Indonesia terdapat organisasi tarekat yang mempunyai otoritas mengakui sah tidaknya sebuah gerakan tarekat yang disebut dengan tarekat mu'tabarah, saat ini dipimpin oleh Habib Lutfi, seorang ulama kharismatik dari Pekalongan.

${ }^{32}$ Komaruddin Hidayat, Wahyu di Langit Wahyu di Bumi (Jakarta: Paramadina, 2003), hal. 3.

\section{DAFTAR PUSTAKA}

Abdurrahman, Moeslim (Ed.). 2003. Muhammadiyah Sebagai Tenda Kultural. Jakarta: Ideo Press \& Ma'arif Institute.

Aziz, M. Ali. 2009. Ilmu Dakwah, Edisi Revisi. Jakarta: Prenada.

Bahtiar, Asep Pumama 2004. Membaca Ulang Dinamika Muhammadiyah: Wacana di Seputar Pergerakan, Kepemimpinan dan Perkaderan. Yogyakarta: LPPI UMY.

Baidhawy, Zakiyuddin dan Mutohharun Jinan. 2003. Agama dan Pluralitas Budaya Lokal. Surakarta: PSB PS UMS.

El-Muniry, Fahmi Arif. 2006. "Menggagas Pesantren Berbasis Riset: Dari Mengaji ke Mengkaji”, Dalam Mihrab, Edisi II Tahun IV, 2006.

Hidayat, Komaruddin. 2003. Wahyu di Langit Wahyu di Bumi. Jakarta: Paramadina.

http://slamlib.com. 
http://www.cmm.or.id.

Jabrohim. 2005. Membumikan Dakwah Kultural.Jakarta: Suara Muhammadiyah. Ma'arif, Syamsul (Peny.). 2007. Potret Gerakan Dakwah NU. Jakarta: PPLDNU Publishing.

Mile dan Huberman. 1992. Analisis Data Kualitatif. Jakarta: UI-Press.

Muchlas, Imam. 2006. Landasan Dakwah Kultural. Jakarta: Suara Muhammadiyah.

Pimpinan Pusat Muhammadiyah. 2005. Dakwah Kultural Muhammadiyah, Cet. Ke-2. Jakarta: Suara Muhammadiyah.

Pimpinan Pusat Muhammadiyah. 2005. Dakwah Islam Kontemporer. Jakarta: MTDK. 